\title{
The Féerie between Stage and Screen
}

\author{
Frank Kessler ${ }^{1}$
}

In the November 21, 1896 issue of La Nature the readers of this popular French scientific journal could learn about a new moving image machine built by Georges Demeny. ${ }^{2}$ The former assistant of chronophotographer Étienne-Jules Marey was by then working with Léon Gaumont, who had taken over the Comptoir général de photographie in July 1895 and was now exploring the commercial possibilities of animated pictures. ${ }^{3}$ On page 393 of the article, an illustration showed a group of ballet dancers on "real-size images from a 35-meter-long strip destined to be projected as part of a féerie [fairy-play] at the Châtelet theater by means of the Demenÿ Chronophotograph.” In the main text the author explained that the strip consists of 1,000 photographs, all of which were hand-colored, and that this produces a very beautiful effect. The article continued with an explanation of how a positive print can be made by using the very same machine that had been employed to record these images. Even though mentioned only in passing in an otherwise rather technical description of the apparatus and its functioning, the event referred to here in the future tense is a remarkable one indeed. Less than a year after the public presentation of the Lumière Cinématographe at the Salon indien on the Boulevard des Capucines in Paris, one of the theaters in the French capital apparently had the intention to project a short strip of film as part of one of its shows.

Almost two decades later, an article by Edmond Floury in Le courrier cinématographique commemorated this, as he called it, "first application of the kinematograph in a theater." The author explained that the rapid success of the new medium in many different venues along the Parisian boulevards had pushed the directors of the Châtelet, "always on the look-out for something original," to bring the "grand novelty of the day" to their theater. ${ }^{4}$ This retrospective appreciation becomes even

A Companion to Early Cinema, First Edition. Edited by André Gaudreault, Nicolas Dulac, and Santiago Hidalgo.

(C) 2012 John Wiley \& Sons, Ltd. Published 2012 by John Wiley \& Sons, Ltd. 
more interesting when one considers that in 1896, at the Châtelet, the very same Edmond Floury held the position of technical director. So in the article he in fact referred also to his own viewpoint when stating that the board of the theater (on which he was joined by his brother) opted for animated pictures as a special attraction in the féerie spectacle they were going to produce. As the text further revealed, the play in question was La biche au bois (The doe in the wood), and that the kinematograph was used in it in one particular scene.

The question arises, however, how spectacular and sensational the appearance of animated photography in the context of this stage féerie really was. If, a mere eighteen years after the fact, the readers of Le courrier cinématographique were presented with this event as something that had all but disappeared into oblivion, one wonders to what extent theatergoers had actually perceived these 35 meters of film projected as part of a stage play as something truly remarkable. How, in other words, did the audience experience kinematographic images in late 1896 when they were incorporated into a type of live performance which itself was supposed to draw principally on spectacular effects and visual splendor?

The significance of this question extends beyond the case of the Châtelet féerie. In a certain sense it is usually presumed that the advent of the kinematograph did have both an immediate and far-reaching effect on Western visual culture. If Antoine Lumière allegedly thought that his invention was one "without a future," conventional - and of course retrospective - wisdom has it that he was quite wrong indeed. ${ }^{5}$ The extraordinary pace at which animated photography, in just a few years, developed into a major form of popular entertainment and an important industry suggests that the impact of moving pictures on the visual culture of its day was considerable, to say the least.

But did audiences actually perceive the advent of the kinematograph in this manner? Was it really seen as a transformation of the various "cultural series" into which it was integrated? How did moving images compare to, or compete with, other forms of visual entertainment? Such questions need to be addressed if we want to avoid the trap of taking for granted the idea that moving pictures eclipsed older forms of visual entertainment as soon as the new medium appeared on the scene. ${ }^{6}$

\section{The Stage Féerie: Stunning Magic and Visual Splendor}

To assess the possible effect of kinematographic projections as part of a stage féerie, it is necessary to look briefly at this theatrical genre and its position within the realm of dramatic art. Around 1910, Paul Ginisty, a former director of the Théâtre de l'Odéon in Paris, published a book on the history of the féerie, probably one of the first, and still one of the few on this subject. ${ }^{7}$ His account, however, was already a somewhat nostalgic one, and in fact the féerie is described here as a form 
of popular theater that captivated the audience with its rather naive kind of magic, but was threatened on the one hand by an overload of sensationalist effects and on the other by the increasing sophistication of spectators no longer willing to give in to its charms.

Ginisty's book dates the origins of the genre back to the sixteenth- and seventeenth-century ballets at the royal court, which adapted legends and fairy tales, and to the so-called pieces à machines (machine plays) that were created to enchant their audiences with spectacular effects produced with the help of intricate stage mechanisms. ${ }^{8}$ There were also, according to Ginisty, the three genealogical strands that came together in the féerie: ballets, fantastic and magical subject matter, and dazzling displays of visual splendor and stage craft. These traditions made their appearance in various ways throughout the eighteenth century in fairground theaters, but also in more prestigious institutions such as the Comédie-Italienne, the Comédie-Française, and the Opéra-Comique. ${ }^{9}$ The genre Ginisty refers to as "modern féerie" took shape at the end of the eighteenth century with Le pied de mouton, a play that premiered in 1806, functioning as the "model féerie," the basic narrative patterns of which were "done over and over again." 10 The genre established itself during the first half of the nineteenth century, mainly in the theater district along the Boulevard du Temple in Paris. ${ }^{11}$ This was the period during which most of the "classics" of the genre were staged for the first time: Les pilules $d u$ Diable, Les mille et une nuits, La biche au bois, and many others. But already by 1866 , the writer Théodore de Banville was looking back on this period with nostalgia:

In order to imagine it as it was then, one has to dream up some sort of a compromise between the theaters where operas are played and those small shows where we can see the pantomimes. Spectacular sets representing Heaven or Hell, and as sceneries down here on Earth the most rugged mountainsides with streams, waterfalls and decrepit pine trees up on a cliff; complicated machinery, tricks, illusions, flights through the air, Bengal fire; armies of ballet dancers, supernumeraries and characters amalgamating all the mythologies and all the chivalric periods in their lavish and pretentious costumes: that was the overall effect of boulevard theater at that time when the spectacle still was the only nourishment given to the people's artistic appetites. ${ }^{12}$

In this passage de Banville not only enumerates the most important ingredients of the féerie genre; he also emphasizes the fact that its spectacular effects aimed at enthralling a popular audience. However, his use of the past tense here, as well as the retrospective attitude he adopts, clearly designates this description as referring to a bygone era.

According to Ginisty, Jacques Offenbach's Voyage dans la lune from 1875 can be considered "the beginning of an evolution" in which modern technology comes to supplement traditional fairy magic. D'Ennery's Le voyage à travers l'impossible is even seen as introducing something like a "scientific element." ${ }^{13}$ But even this turn toward the modern era did not save the féerie from declining. Shortly before Ginisty published 
his book, in 1909, Adrien Bernheim, a government official in charge of subsidized theaters, mourned the imminent end of the genre in an article entitled "La féerie se meurt" ("The féerie is dying"). Published in the popular magazine Touche à tout, this text also took a somewhat nostalgic point of view: "What I like above all about the féerie," he remarks, "is the utter naïveté it radiates." ${ }^{4}$ For him, as indeed for Ginisty, in the final instance the main problem for the time-honored genre was not so much its difficulty in staying up to date, but rather the fact that the modern theatergoers no longer seemed to appreciate the naively magical atmosphere it created.

In spite of all the transformations the féerie underwent in the course of time, however, its main features appear to have remained more or less unchanged. In keeping with the traits highlighted by Ginisty, Arthur Pougin defined the féerie in his dictionary of theater terms from 1885 as follows:

The féerie is a spectacular play showing a fantastic or supernatural subject where the miraculous element dominates. Thanks to this element, which allows the play to neglect the logic of facts as well as ideas, the action can develop freely in a conventional world, without having to worry about plausibility. Its sole objective is to present the splendor, the illusions and all the power that the luxurious staging, the most lavish costumes, the gracefulness of the dances and the charms of music can provide. In other words: everything which a most spectacular, most strange and immensely varied scenographic display can come up with to surprise, amaze and enchant the audience. ${ }^{15}$

This definition not only identified the féerie as a kind of "theater of attractions," but also as a type of performance necessitating considerable logistical and financial investment in order to create all these visual splendors. As Floury explained in a two-part article published in La revue théâtrale in 1906, such a scène dite à grand spectacle required large sums of money indeed, but was also expected to generate most of the revenue to sustain a theater's entire season. ${ }^{16}$ In order to ensure the success that was of vital importance for this enterprise, the play was produced step by step, calling in specialists at every stage. Authors were called upon to develop a play around a predetermined subject, elaborating one act after another, parts of which had to be rewritten whenever a new idea called for modifications. Once the cast was recruited, the high points of every act - the clous, literally "nailing down" the effect - were to be found. At least three of these had to be original enough to provoke the enthusiasm of audiences and critics alike. This might demand additional investments, either in complicated tricks and effects or in dancers and other performers, of whom one hoped they could provide something completely out of the ordinary. Once these high points had been determined, the rest of the scenes could be written to tie everything together. ${ }^{17}$ A féerie, in other words, was seen as a commercial enterprise that brought with it considerable financial risks, but also, at least potentially, substantial profits, and thus needed to be meticulously planned. The main attractions in particular had to be carefully calculated in their effects. 
Bernheim, in the article from 1909 quoted above, attributed the decline of the féerie to the very fact that the financial risk involved with this kind of show was regarded - and taxed - as being no different from other forms of dramatic art. But while ordinary plays, both comedies and dramas, could be staged at rather modest cost, the féerie required investments of an entirely different order. By 1909, according to Bernheim, the Châtelet was in fact the only stage left that was prepared to take such financial risks, and the only reason it could do so was that there was no competition left. ${ }^{18}$

\section{Châtelet 1896: La biche au bois}

To return to the La biche au bois staged at the Châtelet at the end of 1896, the role of the kinematograph in this show needs to be considered against the background of the generic characteristics mentioned above. What was the function of the animated photographs and how did they compare to the other attractions the play had to offer to its audience?

When the directors of the Châtelet decided to stage La biche au bois, they chose a play that had been presented and readapted more than once since it was first produced in $1845 .{ }^{19}$ One commentator, Charles Buet, remarked that this might be "a way not to go bankrupt, but not a way to make a fortune"; he added somewhat disparagingly that even the prompter would be capable of staging this kind of féerie. ${ }^{20}$ This, however, should be considered a rather exaggerated statement, given the enormous amount of creative and commercial energy that such an enterprise demanded. The condescendence evident in Buet's article is undoubtedly due to the fact that a féerie was hardly seen as a form of "serious" theater. This is confirmed by Edmond Stoullig's review of the play in Le monde artiste, published one week after its première on November 14, 1897. Stoullig explained to his readers that a theater critic had no business judging a féerie, especially when it was a reprise: "The main, if not the only appeal of such a new run resides in the splendor of its mise en scène." ${ }^{21}$

So while La biche au bois was certainly not considered by critics to be an important event in the 1896-7 theatrical season, it still drew considerable attention, as in a certain sense it was the grand féerie of the season. As evidenced by the Almanach des spectacles, published annually by Albert Soubies, not many plays of this genre were performed at the time, the reason being, to begin with, that not many theaters were able to provide the complex stage machinery needed for the various tricks and high points, which were, after all, the main ingredients of this type of production. In addition, the auditorium had to be big enough to seat the kind of crowd such a spectacular show had to pull in if there was to be a payback on the large sums of money the staging of a féerie required. The Châtelet had room for 2,600 spectators, so it was one of the few theaters in town that did have the seating capacity to turn an expensive show like La biche au bois into a financial success. ${ }^{22}$ 
Given the overall presence of commercial considerations in the preparations for La biche au bois, it is all the more important to understand exactly the role that the kinematograph, or rather Demenÿ’s Chronophotograph, played in this enterprise. Among Léon Gaumont's business letters there is a project for a contract with the Châtelet, dated July 20, 1896. ${ }^{23}$ According to this document Gaumont, in addition to producing the film, rented out the projector and equipment as well, for which he asked 30 francs a day and a guaranteed income of 500 francs, while the production of the negative was billed at 125 francs. For every positive print he charged 75 francs, demanding that they were to be used exclusively for the show at the Chatelet. Gaumont also requested that the posters specify that the animated projections were executed with a Demenÿ machine manufactured by the Comptoir général de photographie in Paris. For Gaumont this undertaking was apparently not simply a way to make money from the Chronophotograph; he also seized the opportunity to turn this into a public relations affair that would help him promote the new apparatus.

It is difficult to say what part exactly the production and projection of the moving images represented with regard to the overall budget of La biche au bois. Taking into consideration that the play was performed 140 times during the 1896-7 season, however, and that with the matinee of January 3, 1897 it brought in the best earnings of the entire year, namely the sum of 12,972 francs, the amount of money spent on the Chronophotograph may not have been one of the largest investments the directors of the Châtelet had to make for this show. ${ }^{24}$

So how exactly did the animated photographs function within the mise en scène of La biche au bois? Floury, in his article from 1914, gave a quite detailed description of the scene in question. Three years earlier Jacques Ducom, who in 1896 had been responsible for staging and shooting the picture, had published his own account of the way the Chronophotograph was used in the play. ${ }^{25}$ According to these sources, the projections unfolded as follows: one of the characters of the play, a seneschal, is afflicted by a fly and its family living in his nose. This misfortune is the result of a curse a fairy inflicted upon him a long time ago, because he had neglected to invite her to his daughter's baptism. In one scene, the nose is shown extraordinarily enlarged. According to Ducom and Floury, this is due to the actions of a benevolent fairy trying to help the seneschal get rid of the insects, while the libretto states that the nose is being examined with a microscope. ${ }^{26}$

This scene was executed by means of a magic lantern projection, probably using a slide with a moving mask, so that the nose indeed seemed to get bigger and bigger. This was then combined with the moving picture showing a scene with a group of ballerinas who appeared to execute a devilish dance on top of the nose, torturing the poor man with forks and hammers. The film was shot on $58 \mathrm{~mm}$ film stock and hand-colored. ${ }^{27}$ The filming took place on the roof of the Châtelet theater, and both Ducom and Floury relate that people passing by the Place du Châtelet looked up in amazement. To shoot the scene, Ducom used a small stage on which the dance was performed against a black backdrop, so that the moving images could be integrated into the set by being projected from the back of the stage. 
During the performance of the féerie, the projections of both still and moving images were thus entirely incorporated into the action of the play. They functioned much more in the line of what now is called a special effect, rather than being highlighted as an autonomous act, as would be the case, for instance, with the aerial ballet executed by a group of dancers from Blackpool brought in especially for the show. ${ }^{28}$

Jean-Jacques Meusy quotes an article in Le Gaulois stating that the kinematograph was the high point of the piece, and a contemporary text by the author Georges Brunel referred to it as having a "most charming effect." Reviews of La biche au bois written by theater critics, however, tend to see the Blackpool dancers' aerial ballet as its uncontested highlight. ${ }^{29}$ Looking back at the $1896-7$ theatrical season, Stoullig added that in general the ballerinas in La biche au bois were quite pretty and also rather sparsely dressed..$^{30}$ There were thus other "attractions" on the stage of the Châtelet that clearly drew the attention of the critics more than the contribution of a new technology. ${ }^{31}$

In this respect, one can indeed observe that the members of photographic circles, compared to theater people, greeted the scene filmed for La biche au bois with much more positive reactions. Not only was it mentioned, as we have seen, in an article in La Nature dedicated to Demenÿ's Chronophotograph (and not in a piece on new developments in the realm of stage effects, for example), it was also referred to in a report on the meeting of the Société d'Études Photographiques de Paris in April 1897 as "le ballet du Châtelet" without any further explanation, which leads us to infer that the reference was familiar to readers. ${ }^{32}$ The film was offered for sale under this title in the first Gaumont catalogue. The explanation given there refers to it also as the "Ballet $d u$ feu that was part of La biche $d u$ bois and had a good deal of success in a large number of performances of this play." ${ }^{33}$ Stills from the film were also published in the Annuaire de la photographie $1897 .{ }^{34}$

According to Brunel, the moving images were projected so that they appeared more than 5 meters high and were perfectly sharp. ${ }^{35}$ The audience may have experienced a fair bit of flicker, however, as this was a problem discussed extensively at that time by the Societé d'Études Photographiques de Paris, of which Léon Gaumont was a relatively active member that year. In the April 1897 session, to which Gaumont had brought his Châtelet ballet scene, he also presented a new device that was supposed to help attenuate this inconvenience. Members of the society having experienced a reduction of flickering when waving a hand with the fingers spread in front of their eyes during the projection, Gaumont constructed a kind of a metal fan with square holes in it that could be used to obtain the same effect. ${ }^{36}$ Such experiments do raise the question whether the spectators in the Châtelet theater also experienced eye strain from flicker. As the projection of the film strip lasted only a few seconds, this may have been negligible, yet it could still have had an influence on the overall impression people got from the new technology as part of a stage show.

When assessing the historical role of the Demenÿ Chronophotograph in La Biche au bois, one has to be aware of the fact that moving images were but one 
ingredient in a very elaborate show and that they quite probably made less of an impression on audiences than other attractions the performance had to offer. In more theoretical terms one might say that the projected images were so completely integrated into the cultural series féerie that viewers and critics generally did not experience them as a new and autonomous medium. ${ }^{37}$ For people linked to the photographic profession, on the other hand, this probably appeared as a rather successful and promising experiment helping to explore the possible ways in which animated photographs could be used and marketed. Turning to the relatively well-established business of commercial stage entertainment must have seemed a quite obvious choice. There were in fact similar initiatives more or less at the same time. In February 1897 Maurice Curnonsky praised the use of a kinematograph in the Paris Gala at La Bordinière. The directors Elhem and Meudrot apparently incorporated footage of the Tsar's visit to Paris into their show, allowing the audience "to relive the unforgettable moments when we were so proud to have almost become Russians." ${ }^{38}$ Unlike La biche au bois, these images were not produced for the occasion, and in fact constitute an example of the incorporation of actualities into a different cultural series from the féerie. So while in both cases the same type of technology was employed, the uses differed considerably (a fact that also makes discussions about "firsts" in this context quite pointless).

One other point deserves mention with regard to the continuation of such practices. On May 4, 1897, the terrible fire at the Bazar de la Charité caused by an unfortunate action of the projectionist's assistant claimed 129 lives. While further research into the consequences of the disaster is necessary, one can presume that theater directors may have become more reluctant to integrate such a potential fire hazard into a stage show. ${ }^{39}$

\section{Châtelet 1905: Les 400 coups du diable}

Almost a decade later, again at the Châtelet theater and premiering again at the end of the year during the holiday period, a big new féerie was presented to Parisian theatergoers. Written by Victor de Cottens and Victor Darlay, Les 400 coups $d u$ diable included two tableaux during which films were projected. The manufacturer who was asked to produce these scenes was none other than Georges Méliès. In several respects the general circumstances under which this Châtelet féerie was performed during the 1905-6 season were not that different from the situation in 1896-7. The production was hailed in a number of periodicals and illustrated magazines as a spectacular enterprise, a play belonging to a time-honored tradition, and a new work capable of living up once again to the expectations of children and grown-ups alike. And just like La biche au bois, this play, too, drew many spectators and was performed 216 times during the 1905-6 season. The matinees on December 25 and January 1 produced the best box-office results for the Châtelet of 
1905 and 1906, grossing 15,357.50 and 15,332.50 francs, respectively. ${ }^{40}$ On the other hand, the kinematograph was no longer a novelty by that time, and Méliès himself, for instance, regularly advertised his shows at the Robert-Houdin theater as "Prestidigitation et cinématographe" in the Gazette des Théâtres. ${ }^{41}$ The question thus becomes whether its being a more established form of visual entertainment affected the role of animated photography in such a stage production: was it a more prominent and, consequently, more acknowledged entertainment in 1905-6 because the audience was now more easily able to identify the new technology's contribution to an old-fashioned kind of spectacle?

The entire libretto for Les 400 coups du diable is reproduced in a supplement to the February 1906 issue of an illustrated monthly magazine for youth, Mon beau livre. This publication contains not only the entire text of the play and a number of illustrations, but also some technical information and the names of collaborators, such as the set designer Amable, the choreographer, a Miss Stichel, and the director of a pantomimic interlude, James Price. And of course Méliès is credited with the creation of two "kinematographic scenes." ${ }^{2}$ The fact that the libretto of the play was reproduced in a magazine for young readers is quite indicative of the target group of such a féerie. Various details suggest, however, that the text published in Mon beau livre was more or less identical to the booklet the audience could purchase in the theater. The information referring to the artists responsible for the different attractions is clearly addressed to adult theatergoers. This confirms once again the complex status of the féerie as a stage genre at that time: it was manifestly considered a form of play that, mainly because of its fantastic story line, appealed to children and adolescents, while at the same time the extraordinary efforts put into the elaboration of surprising tricks, sensational displays, spectacular ballets, and magnificent sets provided a broad range of visual pleasures to the sophisticated grown-up spectator.

The kinematographic scenes created by Méliès were projected in the course of the first and the second act of the play and constituted nos. 2 and 12 of the 34 tableaux found in Les 400 coups $d u$ diable. In the first tableau, it is discovered that a good but terribly lazy genie had simply hidden away in a cupboard all the requests that humans had addressed to him. As a punishment he is banished and has to live on Earth. Here he has to face the Devil and can only vanquish him by finding a number of talismans. In the second tableau he has to get into a coach that is supposed to take him to his exile. The scene is described in the booklet as follows:

Tableau II

The Trip through the Air

Kinematograph

The coach driver is drunk. Discussion between the Good Genie leaning out of the door and the coach driver whipping his horse. The coach rushes off. The Good Genie is terrified. The coach passes a star that is inhabited. The population is agitated, accident etc.... Finally, the banger takes off into space, and just as one can start to 
perceive Earth it flips over. The Good Genie is thrown into space and opens an umbrella to serve as a parachute. ${ }^{43}$

According to Jacques Deslandes and Jacques Richard, the projection of Méliès's film functioned as an interlude, making possible a change of scenery. Méliès had photographed these scenes against a black background so that the screen blended in with the darkened stage. The kinematograph's second appearance, in tableau 12, "The Cyclone," may have served a similar function, as it is combined with an on-stage storm. Having found their first talisman, a rainbowcolored ribbon, the Good Genie and his companion Marius fall prey to the Devil unleashing a tempest.

Tableau XII

The Cyclone

Everything in the marketplace gets blown away: umbrellas, flowerpots, chickens. Everything whirls about and flies away because of the wind. The inhabitants cry out in fear, chimney bricks fall from the roof, and of course the Good Genie lets go of the legendary ribbon, which disappears up in the flies.

The stage gradually falls into darkness.

Gauze veils are lowered behind a calico curtain on which the kinematographed cyclone is projected. The Good Genie and Marius are seen flying by, holding on to chimney bricks.

They touch the treetops of a forest.

The noise is terrible, but stops all of a sudden and everything is calm.

The gauze curtain is lifted and the calico disappears. ${ }^{44}$

Once again kinematographic projection helped to prepare a scene change, as the following tableau presented a panoramic view of Paris in the year 2000. In fact, animated pictures were not the only type of visual medium incorporated in this way into the performance of Les 400 coups $d u$ diable. Several transitions from one tableau to the next were carried out by means of moving panoramas guiding the characters from one place to another.

Looking at the way the kinematographic scenes produced by Méliès were inserted into the overall structure of the play one could argue that they functioned as transitions between attractions rather than as attractions in themselves. It is interesting in this respect that in an article published by a newspaper in New Zealand the scene of the cyclone is indeed highlighted, but no mention is made of the kinematographic scene: "some of the scenes were wonderfully ingenious, including the extraordinary storm scene in the second act. A cyclone rises, whizzing everything about the stage in a lifelike manner. Chimneys come toppling down, people are blown into the air, the winds howl, rain pours on the stage - and all is done by currents of compressed air which are allowed to play with the scenery and with the characters." ${ }^{45}$ While some of the effects described by the journalist, such as the people blown into the air, may in fact have been part of the Méliès picture, 
it is quite obvious that he does not refer explicitly to the projected images. The stagecraft involved in this tableau must have impressed the correspondent much more than the animated photographs. Similarly, Joseph Leroux, a critic writing for La revue théâtrale, listed in his review the costume designer Landolff, the set designers Amable, Jambon, and Bailly, the choreographer Stichel, and the chief technician Colombier, but neglected to mention the creator of the kinematographic scenes. ${ }^{46}$ Félix Duquesnel, writing for Le Théâtre, also praised the splendor of the production without any reference to the projections, while paying special attention to tableau 31:

A panoramic curiosity just has to be mentioned: the 'Review of one hundred thousand men.' They really are one hundred thousand. The prestigious brush of Amable indeed succeeds in mobilizing an entire army. It fills the horizon of an immense plain, just like the battlefield at Sadowa where two million men could easily have destroyed each other. This is where the review of the troops takes place, in shining uniforms, the first ranks passing the spectators with rolling drums and sounding trumpets, while the other parts of the army appear in the far distance. The illusion is complete and the sight is thrilling. ${ }^{47}$

Duquesnel used the term "animated panorama" to describe this attraction. Interestingly, he also emphasized the fact that it provided a complete illusion, an attribute that one might expect to be used to describe the kinematograph. As a matter of fact, there even is an outright negative reaction to the projected images. The anonymous critic of L'art du théatre, just like the author of the article published in the New Zealand newspaper, highlighted the tempest scene among the play's major attractions, again without hinting at Méliès's contribution. Quite on the contrary, he added the following observation: "I rather less enjoyed the kilometers of panoramic sets, which on top of that were prolonged by kinematographic projections." ${ }^{48}$ This critic's aversion to the moving images of both the panoramas and the kinematograph may be voiced in an exceptionally strong manner, but from the reviews consulted in the course of my research it seems evident that the films were not counted among the highlights of the production. This may also have been due to the rather nostalgic attitude that theater critics tended to adopt with regard to the féerie as a stage genre. Looked at from the point of view of childhood reminiscences, the addition of more modern technologies could hardly appear as a positive development, but rather as a threat to the féerie's naive charms. While Méliès had been capable of transferring such enchantments into a form of cinema of attractions and to create a commercially successful type of production, the reverse - to introduce and establish kinematographic views as a new attraction for stage performances - proved to be much more difficult. The various visual delights with which the stage could provide the audience apparently continued to impress critics, at least, much more than the wonders and achievements of the new technology. ${ }^{49}$ Curiously, however, the stage genre is nowadays almost forgotten, 
while film féeries, and in particular those produced by Georges Méliès, can be considered part of the canon of our audiovisual heritage. ${ }^{50}$

\section{Conclusion}

Looking at the place kinematographic projections had in two féerie productions in 1896-7 and 1905-6, a number of observations can be made that concern the historiography of early cinema.

When André Gaudreault ${ }^{51}$ notes that Méliès's filmic féeries are part of the tradition of stage féeries, that they participate, in other words, in this cultural series, he is certainly right. Looking at the use of kinematographic projections in stage productions, however, one also needs to understand that seen from within this cultural series, animated photographs were at best an additional type of attraction, and in general one that had difficulties competing with, let alone outdoing, many of the other spectacular elements of such a show. The novelty aspect of kinematography did not automatically entail superiority of the new technology vis-àvis more established forms of visual entertainment.

Second, animated photography in these years was a technology that functioned in a broad range of dispositifs. ${ }^{52}$ It was attached, in other words, to different types of cultural practices: screen practices, Charles Musser ${ }^{53}$ calls them, but also, as in the case of the féeries discussed above, stage entertainments. In order to understand the emergence and institutionalization of kinematography as a form of popular entertainment, one needs to take into account the fact that such practices did not simply converge into the future institution. What is at stake here, in terms of media history, are not issues of failure or success, but rather the diversity of practices and dispositifs that points toward fields of possibilities rather than toward teleological processes contributing in a linear and selective way to the consolidation of a medium in its dominant form.

Third, these case studies can help us to understand that there were rather different interests and strategies involved on the part of people from a variety of backgrounds engaged with the new technology. The photographers with whom Léon Gaumont discussed the ballet scene he produced for the Châtelet undoubtedly viewed it differently than theater critics; these two groups, in other words, did not have the same frame of reference. This is a point that historians need to take into account when assessing and discussing contemporary reactions to kinematographic projections.

Finally, the example of the féerie on stage and screen illustrates the productivity of a historical approach that does not take as its starting point a normatively assumed identity of media forms, but rather tries to take into account the relative openness of the way in which media dispositifs function in accord, but also in competition, with other such dispositifs, and the complex interactions between 
technologies, textual forms, practices, uses, and spectatorial positions which are at the basis of the phenomena we then designate as media, means of communication, or art forms.

\section{Notes}

1 The author would like to thank the staff of the Bibliothèque de l'Arsenal in Paris for their support, Stéphane Tralongo for letting me use his unpublished work on La biche au bois, Claire Dupré La Tour for her hospitality, and Sabine Lenk for her invaluable help at various stages of his research. This work is part of the Utrecht Media and Performance Research Group's project on Emerging Media.

2 G. Mareschal, "Le Chronophotographe de M. G. Demenÿ,” La Nature 1225 (November 21, 1896): 391-4. These and all other translations from the French are my own, unless stated otherwise.

3 See the introductory texts by Jean-Jacques Meusy and Laurent Mannoni to Les premières années de la société L. Gaumont et Cie. Correspondance commerciale de Léon Gaumont 1895-1899, eds. Marie-Sophie Corcy, Jacques Malthête, Laurent Mannoni, and JeanJacques Meusy (Paris: AFHRC, 1998), 19-23 and 25-7, respectively.

4 Edmond Floury, "Les débuts du Cinématographe au Théâtre du Châtelet," Le courrier cinématographique 24 (June 13, 1914): 6.

5 On the origins of this phrase see Léo Sauvage, L'affaire Lumière (Paris: Lherminier, 1985), 178.

6 On this topic see, for example, André Gaudreault, "The Diversity of Cinematographic Connections in the Intermedial Context of the Turn of the 20th Century," in Visual Delights: Essays on the Popular and Projected Image in the 19th Century, eds. Simon Popple and Vanessa Toulmin (Trowbridge: Flicks Books, 2000), 8-15.

7 Paul Ginisty, La Féerie (Paris: Louis Michaud, n.d. [1910]). An important recent study is Roxane Martin, La Féerie romantique sur les scènes parisiennes (1791-1864) (Paris: Honoré Champion, 2007).

8 Ginisty, Féerie, 12-24.

9 Ibid., chap. 4 and 5.

10 Ibid., 96.

11 Ibid., chap. 10.

12 Théodore de Banville, Les parisiennes de Paris (Paris: Michel Lévy Frères, 1866), 208-9.

13 Ginisty, Féerie, 214. Neither of the plays corresponds with the Méliès films bearing the same title.

14 Adrien Bernheim, "La féerie se meurt," Touche à tout 9 (1909): 359.

15 Arthur Pougin, Dictionnaire historique et pittoresque du théâtre et des arts qui s'y rattachent, vol. 1 (1885; repr., Plan-de-la-Tour: Éditions d'Aujourd'hui, 1995), 360. Both Pougin and Ginisty refer only to the French tradition of such plays; similar forms in other countries are not discussed. After having heard Bryony Dixon's paper at the Sheffield 2005 "Visual Delights III - Magic and Illusion" conference and discussing the topic with her, I realized that nineteenth-century English pantomime shares a number of 
features with the French féerie. The Paris correspondent of a New Zealand newspaper called Les 400 coups $d u$ diable a "fairy play which in everything but in name is very much like our own Christmas pantomime." See "On the Paris Boulevards," Poverty Bay Herald, December 22, 1906. There are also some parallels between the féerie and the Austrian Zauberspiel.

16 Edmond Floury, "La cuisine théâtrale," La revue théâtrale, n.s., 54 (1906): 1387-8. The second part was published under the title "La cuisine théâtrale (suite)" in La revue théâtrale, n.s., 59 (1906): 1517-19.

17 See Floury, "La cuisine théâtrale" and "La cuisine théâtrale (suite)."

18 Bernheim, "La féerie se meurt," 358.

19 See Stéphane Tralongo, "Le 'cinématographe-ballet' et la tradition des images projetées à la scène: la logique de la récupération des clous dans La biche au bois (1896)" (unpublished manuscript, 2010, Microsoft Word file).

20 Charles Buet, "Le théâtre populaire," Revue d'art dramatique, n.s., 1, no. 1 (November 1896): 38. Interestingly, in an article published in the same section of the same periodical in March 1897 another author, Charles Dinamis, discusses the meaning of the term "popular theater" and comes to the conclusion that it is the equivalent of "cheap theater" ("Le théâtre populaire," Revue d'art dramatique, n.s., 1, no. 5 [March 1897]: 365). This, however, is clearly not the case as far as the féerie is concerned, given the financial investments the genre requires.

21 Edmond Stoullig, "La semaine théâtrale," Le monde artiste (November 22, 1896): 742.

22 Alphonse Deville, Rapport. Présenté, au nom de la Commission spéciale des $2^{\mathrm{e}}$ et $4^{\mathrm{e}}$ Commissions, sur les propositions de création d'un Théâtre municipal populaire et sur l'affectation de la salle du théâtre du Châtelet (Paris: Conseil Municipal de Paris, 1897), 21.

23 See Courcy et al., Les premières années, 131-2.

24 For these figures see Albert Soubies, Almanach des spectacles. Année 1896 (Paris: Librairie des Bibliophiles, 1897), 55; and Almanach des spectacles. Année 1897 (Paris: Librairie des Bibliophiles, 1898), 51.

25 Jacques Ducom, Le cinéma scientifique et industriel (Paris: Geisler, 1911), 58-60. This account is quoted extensively in Jacques Deslandes and Jacques Richard, Histoire comparée du cinéma, vol. 2, Du cinématographe au cinéma 1896-1906 (Tournai: Casterman, 1968), 327-8. See also Tralongo, "Le 'cinématographe-ballet'," who, in addition, bases his description on the text of the play that contains additional information concerning the staging.

26 See Tralongo, "Le 'cinématographe-ballet', ' for a detailed discussion of this latter point.

27 Two prints of the film survive, one at the Cinémathèque française, the other at the National Film and Television Archive in Bradford. See Laurent Mannoni, "Une féerie de 1896: La Biche au bois," Cinémathèque 10 (Fall 1996): 117-23.

28 See Floury, "La cuisine théâtrale," 1388.

29 See Jean-Jacques Meusy, Paris - palaces, ou le temps des cinémas (1894-1918) (Paris: CNRS Éditions, 1995), 42. Meusy refers to Georges Brunel's volume Les projections mouvementées, historique, dispositifs, le chronophotographe Demenÿ (Paris: Comptoir général de photographie, 1897). See also the various reviews quoted by Tralongo, "Le 'cinématographe-ballet'," and Stoullig, "La semaine théâtrale," 742.

30 Edmond Stoullig, Les annales du théâtre et de la musique 1896 (Paris: Paul Ollendorff, 1897), 296. 
31 One theater critic, however, did praise the scene: "The two ballets are very well done and some of the tableaux, especially the one with the kinematograph, are sensational." Paul de Chambert, Les poussières de la rampe. Notes théâtrales. Première série (Paris: A. Charles, 1898), 46.

32 A. Villain, "Société d'Études Photographiques de Paris. Séance du 14 avril 1897. Présidence de M. Balagny. (suite et fin)," Le moniteur de la photographie, 2nd series, 4, no. 13 (July 1, 1897): 206.

33 See the pages of the catalogue reproduced in Deslandes and Richard, Histoire comparée du cinéma, 2: 331 .

34 See Mannoni, “Une féerie de 1896," 122.

35 Brunel, Les projections mouvementées, 63, as paraphrased by Mannoni, "Une féerie de $1896, " 118$.

36 Villain, "Société d'Études Photographiques de Paris," 206. In later years the flickering was reduced by using a multi-blade shutter in the projector, but the basic principle remained the same.

37 On the concept "cultural series," see André Gaudreault, Film and Attraction, trans. Timothy Barnard (Urbana, Chicago and Springfield: University of Illinois Press, 2011), especially chap. 4.

38 Maurice Curnonsky, "Le théâtre parisien," Revue d'art dramatique, n.s., 1, no. 4 (February 1897): 294.

39 The possible impact of the fire on the use of kinematographs in theaters has been suggested to me by Sabine Lenk. See also Meusy, Paris - palaces, 57-60, for measures taken by the authorities. In 1908 one author still complained about the fact that the cinema was totally neglected by insurance companies. See Francis Mair, "Le cinématographe et les Compagnies d'assurance," Phono-Ciné-Gazette 42 (December 18, 1908): 472-3.

40 See Albert Soubis, Almanach des spectacles. Année 1905 (Paris: Librairie des Bibliophiles, 1906), 36, and Almanach des spectacles. Année 1906 (Paris: Librairie des Bibliophiles, 1907), 66. According to Meusy, Paris - palaces, 107, the Châtelet by then seated 3,200 spectators.

41 See the advertisements in Gazette des théâtres throughout 1906.

42 Mon beau livre 2 (Paris: Fayard, 1906).

43 Ibid., 2: vi. See also Deslandes and Richard, Histoire comparée du cinéma, 2: 479-81.

44 Mon beau livre 2: xxvi. See also Deslandes and Richard, Histoire comparée du cinéma, 2: 481-2.

45 "On the Paris Boulevards."

46 Joseph Leroux, "Au Châtelet - Les Quatre Cents Coups du Diable," La revue théâtrale, n.s., 49 (January 1906): 1216. Another case in point is Stoullig, Les annales du théâtre, who also enumerates several collaborators to the show, but fails to mention Méliès.

47 Félix Duquesnel, "La quinzaine théâtrale," Le Théâtre 170 (January 1906): 2-3.

48 “Thèâtre $[$ sic $]$ du Châtelet. 'Les Quat'cents Coups du Diable.' Féerie en trente-six tableaux," L'art du théâtre 62 (February 1906): 24.

49 Interestingly, two books dedicated to stage tricks and effects from that period - Alfred de Vaulabelle and Charles Hermandinquer, La science au théâtre: étude sur les procédés scientifiques en usage dans le théâtre moderne (Paris: Henry Paulin, 1908) and Max Nansouty, Les trucs du théâtre, du cirque et de la foire (Paris: Armand Colin, 1909) - both 
deal with the kinematograph and other technologies of animated photography, but do not discuss specific uses of them in stage performances or refer to any examples.

50 All this needs however to be nuanced in the light of the findings presented by Stéphane Tralongo at a conference on Méliès in July 2011 in Cerisy-la-Salle. It seems that numerous critics in the newspapers mentioned and acclaimed the kinematographic scenes. So maybe the authors writing for the specialized theatrical journals had a more "conservative" attitude toward modern media technologies than those writing for the press.

51 See Gaudreault, "Les vues cinématographiques selon Georges Méliès," 121.

52 On this topic see Frank Kessler, "La cinématographie comme dispositif (du) spectaculaire," Cinémas 14, no. 1 (2003): 21-34.

53 Charles Musser, The Emergence of Cinema: The American Screen to 1907 (New York: Charles Scribner's Sons, 1990), 15-54. 